\title{
Factors associated with vocal health and quality of life in teachers/professors
}

Mônica Carneiro Leão de Albuquerque Lopes(1) Sabrina Nathália Fagundes ${ }^{(1)}$

Kristiana Cerqueira Mousinho(1) Mylena Guimarães Cabral Correia(1)

Camila Maria Beder Ribeiro(1) Aleska Dias Vanderlei(1)

(1) Centro Universitário CESMAC, Maceió, Alagoas, Brasil.

Research support source: PSIC - Scientific Initiation Programme CESMAC.

Conflict of interests: Nonexistent

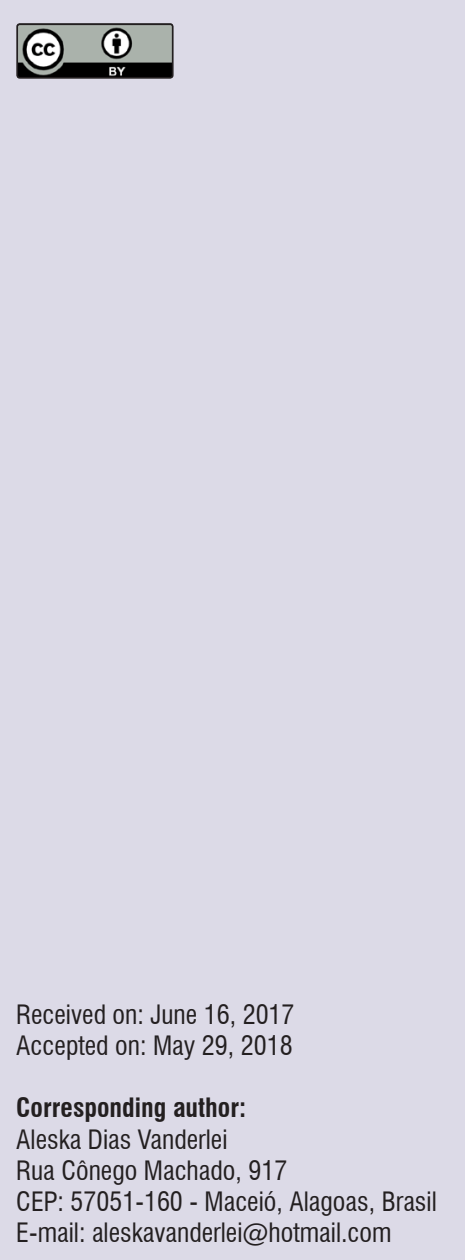

\section{ABSTRACT}

Purpose: to analyze the association of self-reported vocal symptoms with personal, occupational and clinical aspects and relate them to the quality of life of teachers/professors of the federal network of vocational and technological education.

Methods: study carried out with 157 teachers from a federal public institution of vocational and technological education, who answered the World Health Organization Quality of Life questionnaire (WHOQOL-bref), Quality of Life in the Voice (V-RQOL) questionnaire and a data form (on social information, health conditions, vocal symptoms, habits, organization and working environment). Statistical analysis was performed using the Chi-square test.

Results: $29 \%$ of the teachers presented vocal symptoms. The prevalent complaints were dry throat $(38.2 \%)$, cough $(37.6 \%)$ and hoarseness (30.6\%). There was a higher prevalence of symptoms in females. For the WHOQOL-bref, the average was 71.3 points, which is considered regular. The domain with the highest score was the psychological one with 75.3. Regarding V-RQOL, the average score in the global domain was 92.5 points, and the physical score was the most compromised one. $90.5 \%$ of teachers showed low voice impact on quality of life.

Conclusion: although these teachers present vocal complaints, they do not reflect in the limitation of the quality of life.

Keywords: Voice; Quality of Life; Teachers 


\section{INTRODUCTION}

The National Consensus on Professional Voice (CNVP) emphasizes that the voice reflects the physical and mental health of the individual. The occurrence of dysphonia is very common in professions where the voice is used as a working tool. In its final report, the CNVP established the concept of professional voice as the form of oral communication used by individuals who depend on it to perform their occupational activity ${ }^{1}$. According to the Ministry of Health's document, the Department of Environmental Health and Worker's Health, the Work-Related Voice Disorder (DVRT) is any vocal change directly related to the use of voice, during the professional activity that diminishes, compromises or prevents the worker's performance or communication, having it organic changes in the larynx or not ${ }^{2}$.

In the teaching work, the combination of prolonged voice use, individual, environmental and work organization factors, work together to increase the prevalence of vocal complaints. The voice disorder is manifested by the presence of signs and symptoms that may arise simultaneously or not, according to the severity of the case, and may lead to situations of withdrawal from work, with financial and social consequences ${ }^{2}$.

An epidemiological study conducted with 1,651 teachers and 1,614 non-teachers in 27 Brazilian states used a standardized questionnaire and found a higher prevalence of vocal symptoms in the teachers' group. It was concluded, then, that teaching is a high-risk occupation for the development of vocal disorder ${ }^{3}$.

There was an interest in research, in the last decade, to verify the influence of voice changes on quality of life (QoL) in patients and / or subjects who use the voice professionally ${ }^{4-6}$.

Quality of life is a broad, subjective and multidimensional concept that encompasses the subject's perceptions in the physical, psychological and social aspects, considering their values, goals, experiences, needs, culture, patterns and concerns ${ }^{7}$.

Researches that study the self-perception of QoL, in the voice area, use instruments that seek to capture the individual's impression of their own voice, which provides information that contributes to the understanding of vocal awareness ${ }^{8}$.

A systematic review of the literature found that there is a need to increase research on Quality of Life related to the voice of the teacher at different levels of education (Kindergarten, Elementary, High-school or Graduate) and types of schools (Public or Private) that contemplate aspects on the conditions and organization of teaching work'.

Because of the transformations that have taken place in the social and economic context of the country in the last decades ${ }^{10}$, the offer of technical and professional education in Brazil is expanding. In view of these facts, the importance of this research is justified, due to the lack of even greater scientific production related to voice in relation to quality of life, when it comes to technical and vocational education teachers. Thus, it is expected that this research may provoke reflections and proposals to highlight the importance of vocal health.

The aim of this study was to analyse the association of self-reported vocal symptoms with personal, occupational and clinical aspects and relate them to the quality of life of teachers from the federal network of vocational and technological education.

\section{METHODS}

It is a descriptive, observational, cross-sectional, quantitative study. The Research Ethics Committee of the Center has approved it for Post-graduate Studies in Maceió, AL - CESMAC with CAAE number: 49932215.3.0000.0039 from the "Plataforma Brasil". All the participants signed the Term of Free and Informed Consent (TCLE) based on Resolution 466/12 of the National Health Council of the Ministry of Health (CNS / MS).

The data were collected in a Federal Education Institution, whose professors occupy the positions of Professor of Basic, Technical and Technological Education and can teach in the offered teaching modalities, the integrated, the subsequent, the graduation education and also the PROEJA, acting in only one or simultaneously in more than one mode.

In the integrated education, students obtain an intermediate level training in conjunction with professional training, at a technical level in the intermediate level. The subsequent is the professional training course at a technical level, offered to students who have finished high school ${ }^{11}$. The Institute also offers courses aimed at Youth and Adult Education (EJA), aimed to those who did not have access or continuity of studies in primary and secondary education in their proper age ${ }^{12}$. It also has graduate courses available at graduation, baccalaureate and technology levels ${ }^{11}$.

The population covered all active teachers, of both sexes, without restriction as to age, with effective bond, in full and regular activity, making 263 teachers. 
Teachers dismissed for any reason and those who performed only administrative activities were excluded because they presented different organizational and work environment characteristics from the others in relation to vocal demand. The sample was determined in 157 individuals, using the equation for finite populations.

All participants answered two validated questionnaires, the World Health Organization Quality of Life / bref (WHOQOL / bref) ${ }^{13}$ and the Quality of Life in Voice (V-RQOL) questionnaire ${ }^{8}$. A third party form named "Data Collection Form", based on a theoretical reference of the area of Speech-Language Therapy ${ }^{14}$, pertinent to the authors who subsidized the elaboration of the instrument used in the research (Appendix).

The WHOQOL-bref with 26 questions, validated in Brazil, comprising four domains, which aim to analyse physical capacity, psychological well-being, social relations and the environment, was used. The teachers can present their answers by means of the variable score from one to five, being score one the worst condition and five, the best one. The WHOQOL-bref domains are calculated according to the terms defined in the Portuguese validation article. The results of the domain scores show values between zero and one hundred, with the worst being the closest to zero and the best, the nearest to 100 . Thus, an individual with a score equal to 50 for a particular domain can be considered median in this particular domain ${ }^{13}$.

The Quality of Life in Voice (V-RQOL) questionnaire evaluates the Quality of Life related to the voice, and is based on the subjectivity of the teacher, who also assigns a scale from 0 to 5 according to his perception. This is a standardized inventory - Voice Related Quality of Life (V-RQOL) ${ }^{15}$ translated and validated into Portuguese $^{8}$. The V-RQOL contains ten questions and examines the relationship between quality of life and voice in three domains: physical (questions 1, 2, 3, 6, 7 and 9), social emotional (questions 4, 5, 8 and 10) and global, this latter aggregated to the previous two. The protocol makes it possible to calculate the scores (sum of points), which ranges from 0 (worst) to 100 (best), with the maximum score indicating a better quality of life related to voice $^{8}$.

The "Data Collection Form" addressed social information (age, gender), the organization of the teacher's activities, characteristics of the environment and work organization, health conditions, vocal symptoms and habits related to the use of voice.

The data obtained by the questionnaires were tabulated in the Excel 2010 program (Microsoft Office ${ }^{\circledR}$ ). Next, the descriptive statistical analysis (absolute and relative frequency) of the variables collected in the Data Collection Form, the WHOQOL-bref scores and the V-RQOL in each of the domains was used. Subsequently, the verification of inferential statistics was performed, using the non-parametric association test $x^{2}$ (Chi-square), through the BioEstat ${ }^{\circledR} 5.0$ program, to analyse the associations between self-reference of three or more vocal symptoms and the cross-referencing between the various variables studied (social characteristics, environment and work organization, behaviours and habits related to health, diseases). A minimum significance level of $5 \%(p \leq 0.05)$ was considered in order to reject the equality hypothesis.

\section{RESULTS}

The data show that $29.3 \%$ (46) of teachers suffer from three or more self-reported vocal symptoms. Among the prevalent complaints were $38.2 \%$ (60) with dry throat, $37.6 \%$ (59) with cough, $30.6 \%$ (48) with hoarseness and $27.4 \%$ (43) reported pain or burning in the throat.

Table 1 presents the description of the social characteristics and work environment collected in the Data Collection Form and their association to the presence of three or more vocal symptoms collected. 
Table 1. Relationship between social and work environment characteristics reported by teachers and complaints of vocal symptoms

\begin{tabular}{|c|c|c|c|c|c|c|c|}
\hline \multirow{3}{*}{ Variable } & \multicolumn{4}{|c|}{ With three or more symptoms } & \multirow{2}{*}{\multicolumn{2}{|c|}{ Total }} & \multirow{3}{*}{$\mathbf{P}$} \\
\hline & \multicolumn{2}{|c|}{ No } & \multicolumn{2}{|c|}{ Yes } & & & \\
\hline & n & $\%$ & $\mathbf{n}$ & $\%$ & n & $\%$ & \\
\hline \multicolumn{8}{|l|}{ Gender } \\
\hline Males & 79 & 50.3 & 25 & 15.9 & 104 & 66.2 & \multirow{2}{*}{0.0425} \\
\hline Females & 32 & 20.4 & 21 & 13.4 & 53 & 33.8 & \\
\hline \multicolumn{8}{|l|}{ Age range } \\
\hline $21-30$ & 3 & 1.9 & 1 & 0.6 & 4 & 2.5 & \multirow{5}{*}{0.7062} \\
\hline $31-40$ & 27 & 17.2 & 13 & 8.3 & 40 & 25.5 & \\
\hline $41-50$ & 40 & 25.5 & 13 & 8.3 & 53 & 33.8 & \\
\hline $51-60$ & 32 & 20.4 & 17 & 10.8 & 49 & 31.2 & \\
\hline $61-70$ & 9 & 5.7 & 2 & 1.3 & 11 & 7.0 & \\
\hline \multicolumn{8}{|l|}{ Noise } \\
\hline No & 5 & 3.2 & 2 & 1.3 & 7 & 4.5 & \multirow{3}{*}{0.7937} \\
\hline Tolerable & 87 & 55.4 & 34 & 21.6 & 121 & 77.0 & \\
\hline Unpleasant & 19 & 12.1 & 10 & 6.4 & 29 & 18.5 & \\
\hline \multicolumn{8}{|l|}{ Use of Chalk } \\
\hline No & 108 & 68.8 & 45 & 28.7 & 153 & 97.5 & \multirow{3}{*}{0.5370} \\
\hline Sometimes & 2 & 1.3 & 0 & 0.0 & 2 & 1.3 & \\
\hline Frequently & 1 & 0.6 & 1 & 0.6 & 2 & 1.3 & \\
\hline \multicolumn{8}{|l|}{ Temperature } \\
\hline Good & 47 & 29.9 & 22 & 14.0 & 69 & 43.9 & \multirow{3}{*}{0.7570} \\
\hline Reasonable & 48 & 30.6 & 19 & 12.1 & 67 & 42.7 & \\
\hline Unpleasant & 16 & 10.2 & 5 & 3.2 & 21 & 13.4 & \\
\hline
\end{tabular}

* Statistically Significant Values $(p \leq 0.05)$ - Non-parametric association test $x^{2}$ (Chi-square)

Table 2 shows the professional and organizational characteristics of teachers' work and their association with the recording of three or more vocal symptoms. The average weekly workload was 14.5 (SD \pm 4.72 ), with a minimum of 4 and a maximum of 40 hours. As for the teaching time, it was observed that $44.6 \%$ of teachers have more than 20 years of profession, with 19.4 years \pm 9.246 (Average $\pm S D$ ), minimum 1 and maximum 39 years. 
Table 2. Relationship between professional and work organization characteristics mentioned by teachers and record of three or more vocal symptoms

\begin{tabular}{|c|c|c|c|c|c|c|c|}
\hline \multirow{3}{*}{ Variable } & \multicolumn{4}{|c|}{ With three or more symptoms } & \multirow{2}{*}{\multicolumn{2}{|c|}{ Total }} & \multirow{3}{*}{$\mathbf{P}$} \\
\hline & \multicolumn{2}{|c|}{ No } & \multicolumn{2}{|c|}{ Yes } & & & \\
\hline & $n$ & $\%$ & $n$ & $\%$ & $\mathbf{n}$ & $\%$ & \\
\hline \multicolumn{8}{|l|}{ Weekly Workload } \\
\hline Up to 10 hours & 19 & 12.1 & 12 & 7.6 & 31 & 19.7 & \multirow{3}{*}{0.2809} \\
\hline 11 to 20 hours & 86 & 54.8 & 30 & 19.2 & 116 & 74.0 & \\
\hline Above 20 hours & 6 & 3.8 & 4 & 2.5 & 10 & 6.3 & \\
\hline \multicolumn{8}{|l|}{ Time of Teaching } \\
\hline$\leq 5$ years & 4 & 2.5 & 5 & 3.2 & 9 & 5.7 & \multirow{6}{*}{0.6186} \\
\hline 6 to 10 years & 21 & 13.4 & 8 & 5.1 & 29 & 18.5 & \\
\hline 11 to 15 years & 14 & 8.9 & 6 & 3.8 & 20 & 12.7 & \\
\hline 16 to 20 years & 20 & 12.7 & 9 & 5.8 & 29 & 18.5 & \\
\hline 21 to 25 years & 24 & 15.3 & 8 & 5.1 & 32 & 20.4 & \\
\hline$>25$ years & 28 & 17.9 & 10 & 6.3 & 38 & 24.2 & \\
\hline \multicolumn{8}{|l|}{ Time in the Institution } \\
\hline$\leq 5$ years & 21 & 13.4 & 11 & 7.0 & 32 & 20.4 & \multirow{6}{*}{0.7022} \\
\hline 6 to 10 years & 29 & 18.5 & 12 & 7.6 & 41 & 26.1 & \\
\hline 11 to 15 years & 5 & 3.2 & 3 & 1.9 & 8 & 5.1 & \\
\hline 16 to 20 years & 18 & 11.5 & 8 & 5.1 & 26 & 16.6 & \\
\hline 21 to 25 years & 21 & 13.3 & 9 & 5.8 & 30 & 19.1 & \\
\hline$>25$ years & 17 & 10.8 & 3 & 1.9 & 20 & 12.7 & \\
\hline \multicolumn{8}{|l|}{$\begin{array}{l}\text { Works as a teacher outside the } \\
\text { Institution }\end{array}$} \\
\hline Yes & 4 & 2.5 & 3 & 1.9 & 7 & 4.4 & \multirow{2}{*}{0.4201} \\
\hline No & 107 & 68.2 & 43 & 27.4 & 150 & 95.6 & \\
\hline \multicolumn{8}{|l|}{ Nr. of students } \\
\hline Up to 20 & 31 & 19.7 & 15 & 9.6 & 46 & 29.3 & \multirow{3}{*}{0.5045} \\
\hline 21 to 40 & 66 & 42.0 & 28 & 17.9 & 94 & 59.9 & \\
\hline$>41$ & 14 & 8.9 & 3 & 1.9 & 17 & 10.8 & \\
\hline \multicolumn{8}{|l|}{ Class Intervals } \\
\hline Never & 17 & 10.8 & 4 & 2.5 & 21 & 13.3 & \multirow{3}{*}{0.4052} \\
\hline Sometimes & 61 & 38.9 & 30 & 19.1 & 91 & 58.0 & \\
\hline Always & 33 & 21.1 & 12 & 7.6 & 45 & 28.7 & \\
\hline \multicolumn{8}{|l|}{ Most used teaching method } \\
\hline Exhibition Classes & 74 & 47.2 & 29 & 18.5 & 103 & 65.7 & \multirow{7}{*}{0.5181} \\
\hline Exhibition Classes+ Group Work & 14 & 9.0 & 4 & 2.5 & 18 & 11.5 & \\
\hline $\begin{array}{c}\text { Exhibition Classes }+ \text { Group work }+ \\
\text { others }\end{array}$ & 7 & 4.4 & 5 & 3.2 & 12 & 7.6 & \\
\hline Exhib. Classes + other & 8 & 5.1 & 3 & 1.9 & 11 & 7.0 & \\
\hline Groups + others & 0 & 0.0 & 1 & 0.6 & 1 & 0.6 & \\
\hline Group work & 2 & 1.3 & 0 & 0.0 & 2 & 1.3 & \\
\hline Others & 6 & 3.8 & 4 & 2.5 & 10 & 6.3 & \\
\hline
\end{tabular}

* Statistically Significant Values $(p \leq 0,05)$ - Non-parametric association test $x^{2}$ (Chi-square) 
Regarding the working time of the teachers in the Institution surveyed, $46.5 \%$ of them had up to 10 years of exercise; in contrast, another $31.8 \%$ had more than 20 years of work in the institution. The average working time was 15.3 years $( \pm 10.0)$.

Figure 1 shows the distribution of the teaching levels taught by teachers. The majority (29.3\%) (46) of teachers teach in the "integrated and graduate" classes, $20.4 \%$ (32) only teach at the "graduate" level, while $19.7 \%$ (31) teach exclusively in the "integrated" ones. As we add the percentages, it can be seen that $49.7 \%$ of teachers teach in integrated and graduate education classes, or only in graduate education.

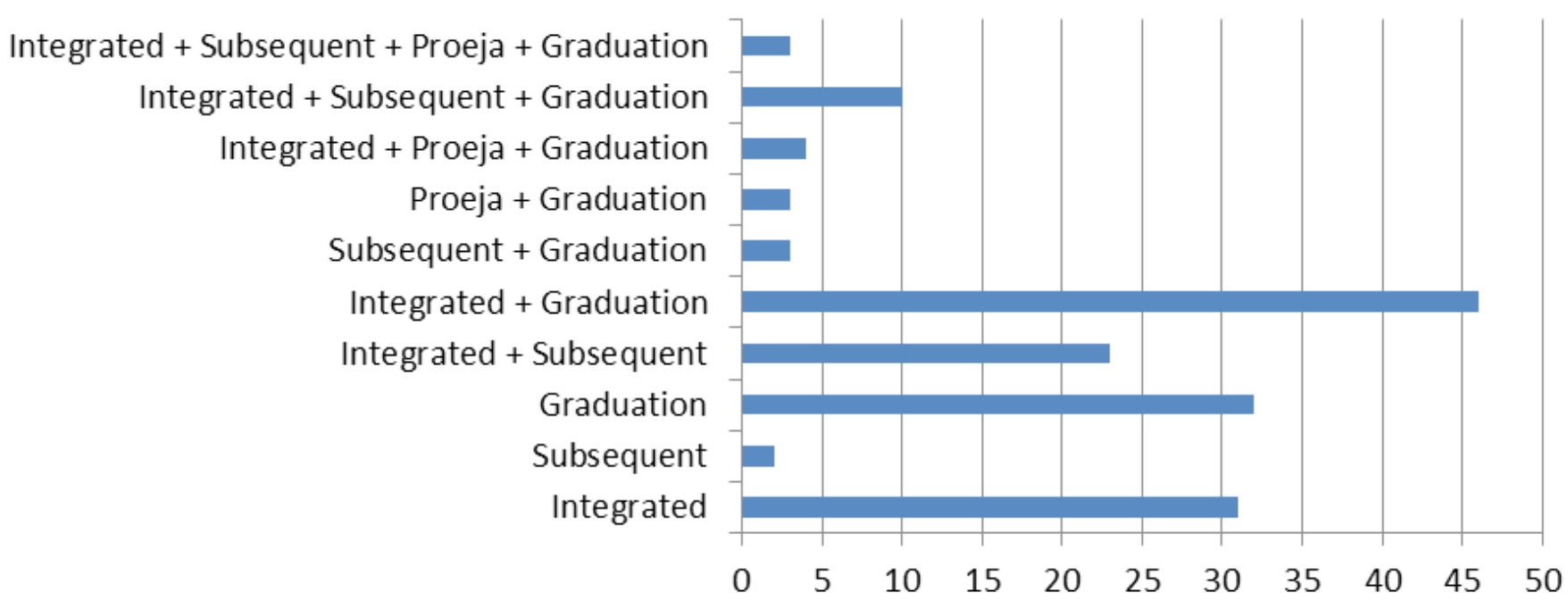

Legend:

Integrated education: students obtain an intermediate level training in conjunction with professional training, at a technical level in the intermediate level.

Subsequent: is the professional training course at a technical level, offered to students who have finished high school.

Youth and Adult Education (PROEJA): comprised by people who did not have access or continuity of studies in primary and secondary education in their proper age.

Graduation: graduate courses available at graduation, baccalaureate and technology levels.

Figure 1. Numerical distribution of teachers according to the teaching modalities in which they teach

Table 3 shows the behaviours and habits related to the health of teachers.

Table 4 shows the data collected from the answers presented by the teachers regarding self-reported diseases.
The prevalence of symptoms according to the gender is exposed in Figure 2.

Table 5 shows the WHOQOL-bref results. The domains average and the quality of life score showed that the teachers presented a regular quality of life. 
Table 3. Relation between health-related behaviours and habits, and record of three or more vocal symptoms

\begin{tabular}{|c|c|c|c|c|c|c|c|}
\hline \multirow{3}{*}{ Variable } & \multicolumn{4}{|c|}{ With three or more vocal symptoms } & \multirow{2}{*}{\multicolumn{2}{|c|}{ Total }} & \multirow{3}{*}{$\mathbf{P}$} \\
\hline & \multicolumn{2}{|c|}{ No } & \multicolumn{2}{|c|}{ Yes } & & & \\
\hline & $\mathrm{n}$ & $\%$ & $n$ & $\%$ & $\mathrm{n}$ & $\%$ & \\
\hline \multicolumn{8}{|l|}{ Water a day } \\
\hline Less than 1 litre & 16 & 10.2 & 9 & 5.8 & 25 & 16 & \multirow{3}{*}{0.6858} \\
\hline 1 to 2 litres & 72 & 45.8 & 27 & 17.02 & 99 & 63 & \\
\hline More than 2 litres & 23 & 14.6 & 10 & 6.3 & 33 & 21 & \\
\hline \multicolumn{8}{|c|}{ Water during the classes } \\
\hline Never & 27 & 17.2 & 9 & 5.8 & 36 & 22.9 & \multirow{3}{*}{0.8103} \\
\hline Sometimes & 54 & 34.4 & 24 & 15.3 & 78 & 49.7 & \\
\hline Always & 30 & 19.1 & 13 & 8.3 & 43 & 27.4 & \\
\hline \multicolumn{8}{|l|}{ Use of voice } \\
\hline Little & 4 & 2.5 & 1 & 0.6 & 5 & 3.1 & \multirow{4}{*}{0.5039} \\
\hline Moderate & 56 & 35.6 & 18 & 11.5 & 74 & 47.2 & \\
\hline Much & 48 & 30.6 & 26 & 16.5 & 74 & 47.2 & \\
\hline Too much & 3 & 1.9 & 1 & 0.6 & 4 & 2.5 & \\
\hline \multicolumn{8}{|c|}{$\begin{array}{l}\text { Constant use of voice in other } \\
\text { activities }\end{array}$} \\
\hline Yes & 33 & 21.0 & 13 & 8.3 & 46 & 29.3 & \\
\hline No & 78 & 49.7 & 33 & 21.0 & 111 & 70.7 & \\
\hline \multicolumn{8}{|c|}{ Doctor/Speech Therapist } \\
\hline Yes & 13 & 8.3 & 14 & 8.9 & 27 & 17.2 & \multirow{2}{*}{0.0047} \\
\hline No & 98 & 62.4 & 32 & 20.4 & 130 & 82.8 & \\
\hline \multicolumn{8}{|c|}{$\begin{array}{l}\text { Profess. Guidance of the use of voice } \\
\text { profissionalmente }\end{array}$} \\
\hline Yes & 12 & 7.7 & 5 & 3.1 & 17 & 10.8 & \multirow{2}{*}{0.9914} \\
\hline No & 99 & 63.0 & 41 & 26.2 & 140 & 89.2 & \\
\hline \multicolumn{8}{|c|}{ Leave of absence for vocal problems } \\
\hline Yes & 3 & 1.9 & 7 & 4.4 & 10 & 6.3 & \multirow{2}{*}{0.0035} \\
\hline No & 108 & 68.8 & 39 & 24.8 & 147 & 93.6 & \\
\hline \multicolumn{8}{|l|}{ Alcoholic Drink } \\
\hline No & 43 & 27.4 & 17 & 10.8 & 60 & 38.3 & \multirow{4}{*}{0.9622} \\
\hline Stopped & 5 & 3.1 & 2 & 1.3 & 7 & 4.4 & \\
\hline Special Occasions & 58 & 36.9 & 24 & 15.3 & 82 & 52.3 & \\
\hline Always & 5 & 3.1 & 3 & 1.9 & 8 & 5.0 & \\
\hline \multicolumn{8}{|l|}{ Smoking } \\
\hline No & 98 & 62.4 & 40 & 25.5 & 138 & 87.9 & \multirow{3}{*}{0.9231} \\
\hline Yes & 3 & 1.9 & 1 & 0.6 & 4 & 2.5 & \\
\hline Ex-smoker & 10 & 6.3 & 5 & 3.1 & 15 & 9.6 & \\
\hline
\end{tabular}

* Statistically Significant Values $(p \leq 0,05)$ - Non-parametric association test $x^{2}$ (Chi-square) 
Table 4. Association between self-reported symptoms / sensations by teachers and record of three or more vocal symptoms

\begin{tabular}{|c|c|c|c|c|c|c|c|}
\hline \multirow{3}{*}{ Variable } & \multicolumn{4}{|c|}{ With three or more vocal symptoms } & \multirow{2}{*}{\multicolumn{2}{|c|}{ Total }} & \multirow{3}{*}{$\mathbf{P}$} \\
\hline & \multicolumn{2}{|c|}{ No } & \multicolumn{2}{|c|}{ Yes } & & & \\
\hline & $\mathbf{n}$ & $\%$ & $\mathbf{n}$ & $\%$ & $\mathbf{n}$ & $\%$ & \\
\hline \multicolumn{8}{|c|}{ Respiratory Allergy } \\
\hline Yes & 21 & 13.4 & 25 & 15.9 & 46 & 29.3 & \multirow{2}{*}{0.0001} \\
\hline No & 90 & 57.3 & 21 & 13.4 & 111 & 70.7 & \\
\hline \multicolumn{8}{|l|}{ Asthma } \\
\hline Yes & 3 & 1.9 & 0 & 0 & 3 & 1.9 & \multirow{2}{*}{0.2602} \\
\hline No & 108 & 68.8 & 46 & 29.3 & 154 & 98.1 & \\
\hline \multicolumn{8}{|c|}{ Rhinitis/sinusitis } \\
\hline Yes & 32 & 20.4 & 27 & 17.2 & 59 & 37.6 & \multirow{2}{*}{0.0004} \\
\hline No & 79 & 50.3 & 19 & 12.1 & 98 & 62.4 & \\
\hline \multicolumn{8}{|c|}{ Pharyngitis/tonsillitis/ laryngitis } \\
\hline Yes & 22 & 14.0 & 22 & 14.0 & 44 & 28.0 & \multirow{2}{*}{0.0004} \\
\hline No & 89 & 56.7 & 24 & 15.3 & 113 & 72.0 & \\
\hline \multicolumn{8}{|c|}{$\begin{array}{c}\text { Gastritis/Gastroesophageal reflux/ } \\
\text { heartburn }\end{array}$} \\
\hline Yes & 26 & 16.6 & 19 & 12.1 & 45 & 28.7 & \multirow{2}{*}{0.0241} \\
\hline No & 85 & 54.1 & 27 & 17.2 & 112 & 71.3 & \\
\hline
\end{tabular}

* Statistically Significant Values $(p \leq 0,05)$ - Non-parametric association test $x^{2}$ (Chi-square)

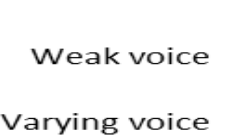

Discomfort when speaking

Tiredness when speaking

Throat pain or burning

Loss of voice

Dry throat

Cough

Voice failure

Hoarseness

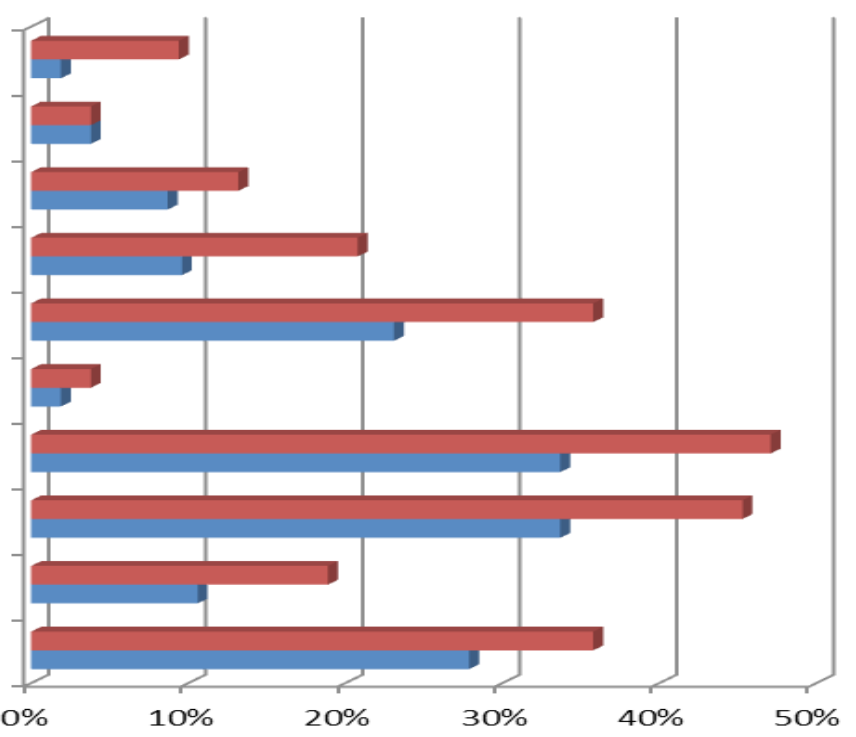

- FEMALE $(n=53)$

- MALE $(n=104)$

Figure 2. Prevalence of vocal symptoms with respect to sex

Table 5. Average and standard deviation of scores according to the domains of the World Health Organization Quality of Life / bref questionnaire (WHOQOL-bref)

\begin{tabular}{lcc}
\hline & WHOQOL & \\
\hline Domains & Average & Standard Deviation \\
\hline Physical Score & 73.0 & \pm 13.4 \\
Psychological Score & 75.3 & \pm 11.9 \\
Social Relations Score & 71.8 & \pm 15.9 \\
Environment Score & 66.1 & \pm 12.7 \\
Quality of life Score & $\mathbf{7 1 . 3}$ & $\pm \mathbf{1 0 . 9}$ \\
\hline
\end{tabular}


The domain of the environment is related to aspects of safety, health, physical environment (climate, noise and pollution), finance, access to information and leisure activities. The issues with the worst scores were related to this domain, specifically question 24 (satisfaction with health services), question 9 (how healthy is the physical environment - climate, noise, pollution, attractions) and question 14 (opportunities for leisure activities). Question 16, which concerns sleep, is part of the physical domain; presented a larger number of unfavourable answers, showing either dissatisfaction or a lot of dissatisfaction.

The overall V-RQOL score was 92.5 ( \pm 8.4), indicating a low voice influence on teachers' quality of life. The closer to 100 the score, the better this ratio. The physical score was $89.3( \pm 10.4)$, and the socialemotional score was 97.3 ( \pm 7.5 ). It is interesting to note that although $29.3 \%$ of teachers reported three or more vocal symptoms, this had no impact on quality of life.
In percentage and quantitative terms in the V-RQOL, the "low impact" scores of voice on quality of life were presented as follows: in the physical domain $81.5 \%$ (128); in the social-emotional $96.2 \%$ (151), and in the global domain, $90.5 \%$ (142).

When analysing questions 1 to 10 of the V-RQOL separately, it is observed that the most committed question is 1 , followed by questions 2 and 9 . It is worth commenting that complaint 1,2 and complaint 9 were those that presented the worse evaluations, both belonging to the physical domain, and are related to the professional use of voice. The number of teachers who considered these issues as a moderate to bad problem was $24.2 \%$ for complaint $1,10.8 \%$ for complaint 9 and $7.6 \%$ for complaint 2 .

Figure 3 shows that the V-RQOL scores were all above 80 , that is, they had a low impact of voicerelated quality of life, however, the domains averages portrayed that the physical domain scores were lower in both sexes, but a little worse in women, especially those who reported three or more complaints in their voices.

\begin{tabular}{|c|c|c|c|c|}
\hline \multirow{2}{*}{ V-RQOL } & \multicolumn{2}{|c|}{ With three or more vocal symptoms } & \multicolumn{2}{c|}{ With less than three vocal symptoms } \\
\cline { 2 - 5 } & Men & Women & Men & Women \\
\hline Physical Domain & 86.8 & 82.9 & 91.3 & 90.1 \\
\hline Social Emotional Domain & 96.2 & 95.8 & 97.3 & 99.0 \\
\hline Global Domain & 90.6 & 88.0 & 93.7 & 93.7 \\
\hline
\end{tabular}

Legend: V-RQOL: Voice Related Quality of Life

Figure 3. Comparison of the average scores obtained in the voice-related quality of life (V-RQOL) protocol by gender, with or without three or more vocal symptoms per domains 
When comparing the V-RQOL scores by gender, in percentage terms, it was found that $13.2 \%$ (7) among women in the sample presented scores of medium to high impact, while among men the percentage was 7.7 $\%(8)$, that is, more disadvantage for the female sex.

Table 6 shows the results of $\mathrm{V}-\mathrm{RQOL}$ in relation to the average WHOQOL-bref scores. We compare the V-RQOL data with the average scores obtained in the
WHOQOL-bref in each domain. We noticed that there is a correspondence between the protocols. This order is reversed in the case of the V-RQOL high impact, whose WHOQOL-bref domain scores were surprisingly better, with values between 83.3 and 95.8. These data reinforce the idea that worse outcomes of the WHOQOL-bref are paired with the worst rates of $\mathrm{V}-\mathrm{RQOL}$.

Table 6. Association of the Voice-Related Quality of Life Protocol (V-RQOL) scores in the Global domain compared to the scores of the various domains of the WHOQOL-bref

\begin{tabular}{ccc}
\hline V-RQOL Global & WHOQOL-Bref & Domains Averages \\
\hline \multirow{3}{*}{ Low Impact $\mathbf{n}=142$} & Environment & 66.7 \\
& Social Relations & 72.1 \\
& Psychological & 75.6 \\
& Physical & 73.7 \\
\hline \multirow{2}{*}{ Medium Impact $\mathbf{n}=14$} & General & $\mathbf{7 2 . 0}$ \\
\hline & Environment & 58.7 \\
& Social Relations & 67.8 \\
& Psychological & 70.8 \\
\hline \multirow{2}{*}{ High Impact $\mathbf{n}=1$} & Physical & 65.0 \\
& General & $\mathbf{6 5 . 6}$ \\
\hline & Environment & 87.5 \\
& Social Relations & 83.3 \\
& Psychological & 95.8 \\
& Physical & 85.7 \\
\hline
\end{tabular}

* a comparative analysis of the V-RQOL (low, medium or high voice impact in the quality of life), with the scores averages obtained in the WHOQOL-bref in each domain.

\section{DISCUSSION}

The associations were performed by comparing the responses of the variables with the occurrence of three or more vocal symptoms, through the application of the statistical test. The literature indicates that teachers' quality of life is related to self-perception of vocal symptoms ${ }^{4,6,9}$.

According to the data collected, it was possible to obtain an overview of the technical and vocational education teachers' self-perception regarding the quality of life and voice, as well as the associated factors that may influence vocal health.

The sample had the highest number of men, which is expected to be for this level of education, although the literature presents most of the publications with the majority of the sample being women. According to the School Census, the profile of teachers is markedly feminine in the initial years and is reversed as they move from Early Childhood Education to High School and Professional Education ${ }^{16}$. Research with primary school teachers showed a higher prevalence of selfreported voice alteration in females ${ }^{17}$.

Likewise, in this study, female teachers also presented a higher percentage of vocal symptoms. It was found that $39.6 \%$ of the female teachers had three or more vocal symptoms, which indicates a greater disadvantage in the female gender, with a statistically significant value. There was a lower index among male teachers, with $24 \%$ of male teachers reporting complaints. Studies have shown that there are important changes in the glottis configuration of women during prolonged phonation with high loudness (subjective 
sensation of intensity), possibly due to constitutional, anatomical differences and double working shift ${ }^{18}$.

The average age of the teachers studied was 47.2 (SD \pm 9.12). The age factor deserves special attention, since the age group between 25 and 45 is considered to have the best vocal efficiency, and as the age advances, structural changes in the larynx may occur and may compromise vocal quality ${ }^{19}$. A study with technical and vocational education teachers found $39 \%$ between the ages of 30 and 39 years, followed by $29 \%$ in the 40-to-49-age group ${ }^{20}$. In this study, there were more teachers aged between 41 and 50 years (33.8\%), but those most affected with vocal complaints were in the age group of 51-60 years old (10.8\%).

Noise was pointed out by $77 \%$ of the teachers as tolerable and $18.5 \%$ judged the noise as unpleasant. Research carried out with higher education teachers referred to the presence of noise in the classroom, but only $48.1 \%$ mentioned voice alteration, and found no significant association ${ }^{21}$. High / unbearable noise in the classroom increases the prevalence of poorer quality of life related to teachers' voice ${ }^{22}$.

The researches show differences as to the influence or not of the high teaching workload on the development of vocal disorders in the teacher ${ }^{4}$. There are studies that did not verify significance between working two shifts or more in the classroom, which characterizes high vocal demand, and the prevalence of symptoms in the voice ${ }^{23,24}$. However, other researchers have found that working in the classroom for 24 hours a week or more in the last six months has demonstrated a significant association with hoarseness in teachers ${ }^{25}$.

In this study, the average classroom workload of less than 20 hours per week may be the reason for not being associated with the presence of three or more symptoms. Another factor worth mentioning is the composition of the study, in which the majority of teachers are male, unlike other studies, in which there is a greater predominance of female teachers, who are more predisposed to vocal alterations ${ }^{17,18,26}$.

The literature shows divergent results regarding the association between vocal alterations and teaching time ${ }^{25}$. Studies present opposite data. Teachers with more years of teaching did not present any more vocal alterations complaints than those with less time of work ${ }^{24}$. A study with teachers of professional and technological education found that $48 \%$ had less than ten years of service, and $8 \%$ had taught for more than twenty-five years ${ }^{20}$. There has been an expansion in the number of schools after the creation of the Federal
Network of Professional, Scientific and Technological Education and the Federal Institutes of Education are a part of it. This consequently increased the number of new servants in recent years ${ }^{10}$, which justifies the number of teachers with more than 20 years teaching and less than ten years of practice in the institution studied.

The majority $(95.6 \%)$ of the teachers in this study taught only in the school assessed. Similar research, with teachers of this same level of education, found that $88 \%$ of the teachers worked only in the institution researched, for years ${ }^{20}$.

We noted that $65.6 \%$ (103) of the educators in this research referred to preferential use of the exhibition classes. Other authors ${ }^{24}$ refer to a preference for this method of teaching in association with audio-visual resources, however, because it requires the constant use of voice, it results in greater vocal exhaustion if the teacher does not have the necessary preparation.

In this study, $29.3 \%$ of the teachers reported activities with voice use besides teaching, and $8.3 \%$ of them reported three or more vocal symptoms. Speech professionals wear the speech device in and out of their work environment, so that they increase voice overload, with possible onset of signs or symptoms after work, generating uncertainty in the cause and effect relationship'.

Only $10.8 \%$ (17) of the teachers who participated in this study sought guidance on the use of voice professionally. Research reports that teachers lack guidance on how to identify and deal with vocal disorders ${ }^{6}$. A recent study found that the minority $(36.4 \%)$ of teachers received some type of vocal orientation regarding voice care $^{27}$.

It was observed that $6.4 \%$ (10) of the teachers needed medical leave or absence from work because of vocal problems. In the State of Alagoas, voice disorders are one of the main reasons for teachers to leave work environment. The number of teachers with vocal alterations has increased since $2003^{28}$.

Regarding the consumption of alcoholic beverages, $52.3 \%$ of them said they only use it on special occasions and $5 \%$ stated that they always drink. Although alcoholism is a factor related to vocal changes, there was no significant association ${ }^{25}$, and this corroborates with research.

Only $2.5 \%$ of the subjects mentioned smoking. Research conducted in 2014 by the Ministry of Health and the Brazilian Institute of Geography and Statistics (IBGE) reveals that the rate of people who smoke 
cigarettes and other tobacco products is $20.5 \%$ lower than that recorded five years ago. Therefore, smoking habit has less and less followers in Brazil, according to IBGE's Special Tobacco Survey (PETab) ${ }^{29}$.

In this sample, the most cited self-reported diseases were $37.6 \%$ rhinitis / sinusitis, $29.3 \%$ respiratory allergy, $28.7 \%$ gastritis / gastroesophageal reflux / heartburn, $28 \%$ pharyngitis/tonsillitis /laryngitis. Problems of the upper airways are an important concern for the teacher's work, since approximately $40 \%$ referred to problems such as sinusitis, rhinitis, tonsillitis, pharyngitis $^{30}$. Another recent study confirms that $37.2 \%$ of teachers report allergy, so demonstrating high prevalence $^{27}$.

Studies have shown that self-evaluation or vocal self-perception has been highly valued. In this study, $29.3 \%$ mentioned three or more self-reported vocal symptoms. These results corroborate with other studies carried out with teachers ${ }^{6,25,28,31}$.

Symptoms such as hoarseness, vocal fatigue, and throat pain in teachers are signs of vocal abuse or voice use in inappropriate work conditions that may contribute to the onset of an occupational disease ${ }^{32}$. Research with teachers from the State School of Alagoas found approximate data regarding the most frequent symptoms: $54.5 \%$ with dry throat, $42.7 \%$ throat clearing and $42.7 \%$ throat burning ${ }^{28}$. Another study mentions $44.3 \%$ with hoarseness, $54.5 \%$ with fatigue when speaking and $53.4 \%$ with dry throat ${ }^{33}$. Researchers found a prevalence of dry throat sensation in $66.6 \%$ and hoarseness in $40.4 \%{ }^{34}$.

Teachers should be warned about the importance of perceiving when the first signs / symptoms of vocal changes appear and seek guidance and treatment, avoiding an aggravation with negative impact from a professional, social and emotional point of view. The teacher without vocal symptoms will be more active in their activities ${ }^{6}$.

In the WHOQOL-bref protocol analysis in this study, the average score obtained was 71.3 (SD \pm 10.9). A similar survey conducted with this same research instrument found a score of 66 as a general average of quality of life, being it considered as a regular score, taking into account that the scale of values varies from zero to one hundred ${ }^{4}$. By comparison, it can be inferred that the WHOQOL-bref results in this study can be considered as a regular quality of life. The most affected domain was that of the environment with 66.1 corroborating with other studies ${ }^{4,35}$.
A study that used this same protocol (WHOQOL-bref) with teachers from public schools had scores similar to those of this study, 68.5 in quality of life, of which 67.6 in the physical domain, 70.1 in the psychological domain, 73.9 in the social domain and 62.4 in the environmental domain ${ }^{36}$. In another research with high school teachers, 68.2 in the physical, 68.2 in the psychological, 70.3 in the social relations, 56.1 in the environment, results very close to those of this research 4 .

A systematic review of the literature, whose objective was to verify the existent researches on quality of life related to teachers' voices, concluded that V-RQOL was the most used protocol in this population?.

The average V-RQOL score in the global domain was 92.4 (SD \pm 8.4). It can be inferred that for teachers of the researched education institution the impact of voice on quality of life was low. Some researches using the V-RQOL found averages of the domains with scores close to those of this research. A similar average of 91.1 points with teachers and 93.0 for the group of non-teachers ${ }^{37}$. However, there are studies, with much lower scores for the global domain, with a score of 65.2 performed with elementary and high school teachers ${ }^{38}$.

It is worth highlighting in this study the fact that all domains of $\mathrm{V}-\mathrm{RQOL}$ were classified within the range of low voice impact in the quality of life (with scores above 80 ), but the most affected domain was the physical one. Literature indicates that the physical aspects, for being related to the discomfort and complaints presented by the use of the voice, facilitate the perception of the individuals to evaluate it as the most shocking. Several studies confirm this fact $\mathrm{ft}^{4-6,9,37,38}$.

In this study, there was a greater impairment of V-RQOL in questions 1,2 and 9, which refer to the difficulties in speaking loudly or being heard in noisy environments, the air ending quickly and having to breathe many times while speaking and still having to repeat what they spoke in order to be understood. Other research indicates that the number of teachers $(51 \%)$ with some difficulty to be heard in noisy environments is relatively high (Question 1$)^{6}$.

Scores remained very near between the genders, with a small disadvantage for females. Another research concluded that when comparing the V-RQOL results of 1304 subjects with varied gender, age and professional vocal usage levels, the impact on quality of life related to a vocal alteration was similarly perceived by both men and women. The total results found in that study were similar in the three domains for men (total 75.5, 
physical 71.3, socioemotional 82.3) and women (total 74.9, physical 70.7, socioemotional 82.1 ${ }^{39}$.

Research with elementary school teachers found values of 72 points in the V-RQOL for the global domain ${ }^{31}$. With university professors, the impact of voice on quality of life was low, with an average global domain score of 82.6 points ${ }^{5}$. Most university teachers presented a good quality of life associated with voice, according to the V-RQOL evaluation, with a median of 97.5 points for the global domain, but a high prevalence of vocal symptoms was evidenced ${ }^{6}$. These results with university professors showed a profile, which is closer to the reality of the professionals of this research with teachers of technical and professional education. Even in this aspect, in which the symptoms did not reflect compromising the quality of life of the teachers.

It is necessary to be alert to the multicausality of dysphonia, linked to environmental conditions and factors and to the organization of work within the school, in addition to the causes related to individual health habits and conditions of each teacher. In this study, significant associations were few, and voice-related quality of life (V-RQOL) indexes in the global domain showed that $90 \%$ of teachers had a "low impact" score. However, it is worth mentioning that out of the 157 teachers participating in this study, $29 \%$ (46) reported three or more vocal symptoms that were negative for the voice, indicating caution and vigilance. Signs and symptoms are present in phases that precede organic changes, such as laryngeal changes observed in more advanced phases of dysphonia ${ }^{40}$.

\section{CONCLUSION}

Almost $30 \%$ of the teachers presented selfreported complaints of vocal symptoms. The prevalent complaints were $38.2 \%$ with dry throat, $37.6 \%$ with cough and $30.6 \%$ with hoarseness. There was a higher prevalence of symptoms in the female gender, with a statistically significant value. The symptoms presented significance with the self-reported presence of some pathologies: respiratory allergy, upper airway diseases, gastroesophageal reflux and gastritis. As for the WHOQOL-bref, the average scores were 71.3 points, with a standard deviation of \pm 10.9 , therefore, considered as regular. The domain with the highest score was the psychological one, with 75.3 and the most harmed was the environment, with 66.1 points.

According to the V-RQOL assessments, the average score obtained in the global domain was 92.4 points. The domain with the most disadvantage was the physical one and the most compromising issues were difficulty in speaking loudly or being heard in noisy environments, the air ending quickly and having to breathe many times while speaking, and the need to repeat what they say in order to be understood. 90.5\% of teachers had low voice impact on quality of life. Thus, it can be inferred that the impact of the voice on the quality of life for the teachers of the professional and technological teaching researched was low. It can be concluded that although the teachers had $29 \%$ of vocal symptoms, these did not reflect in the limitation of quality of life.

\section{REFERENCES}

1. Associação Brasileira de Otorrinolaringologia e Cirurgia Cérvico-Facial (ABORL- CCF). Câmaras Técnicas de Otorrinolaringologia, Medicina do Trabalho e Perícias Médicas do CREMERJ. In: Consenso nacional sobre voz profissional: voz e trabalho: uma questão de saúde e direito do trabalhador. Rev Vox Brasilis [Periódico da Internet]. 2004. [acesso em 2016 jun 25]: 10(10):[about 1p.]. Disponível em:http://www.aborlccf.org.br/secao. asp?s=211.

2. BRASIL. Ministério da Saúde. Secretaria de Vigilância em Saúde/Departamento de Saúde Ambiental e Saúde do Trabalhador. Distúrbio de Voz Relacionado ao Trabalho: Saúde do Trabalhador Protocolo de Complexidade Diferenciada 2011. [acesso em 2016 maio 19]. Disponível em: http:// aborlccf.org.br/imagebank/Protocolo_DVRT.pdf.

3. Behlau M, Zambon F, Guerrieri AC, Roy N. Epidemiology of voice disorders in teachers and nonteachers in Brazil: prevalence and adverse effects. J Voice. [Periódico na Internet]. 2012 [acesso em 2016 jun 23];26(5):[about 10 p.]. Disponível em: http://www-sciencedirectcom. ez133.periodicos.capes.gov.br/science/article/pii/ S0892199711001664.

4. Penteado RZ, Pereira IMTB. Qualidade de vida e saúde vocal dos professores. Rev Saúde Pública [Periódico da Internet]. 2007. [acesso em 2015 jul 14];41(2):7. Disponível em: http://www.scielo.br/ pdf/rsp/v41n2/5638. pdf.

5. Servilha EAM, Roccon PF. Relação entre voz e qualidade de vida em professores universitários. Rev. CEFAC [Periódico da Internet]. 2009. [acesso em 2016 mar 10]; 11(3):440-8. Disponível em: www.scielo.br/pdf/rcefac/2009nahead/42-08 pdf DOI:10.1590/S1516-18462009005000029. 
6. Fabrício MZ, Kasama ST, Martinez ZE. Qualidade de vida relacionada à voz de professores universitários. Rev. CEFAC [Periódico da Internet]. 2010 [acesso em 2016 jun 02];12(2):[about 7p.]. Disponível em: http://dx.doi.org/10.1590/ S1516-18462009005000062.

7. Whoqol Group. The World Health Organization Quality of Life Assessment (WHOQOL): position paper from the World Health Organization. Soc. Sci. Med. [Periódico da Internet]. 1995 [acesso em 2015. Jul 24]; 41(10):[about 6p.]. Disponível em: http://www.ufrgs.br/psiquiatria/psiq/whoqol1.html.

8. Gasparini G, Behlau M. Quality of validation of the brazilian version of the Voice-Related Quality of Life (V-RQOL) Measure. J Voice [Periódico da Internet]. 2009 [acesso em 2016 jun 23];23(1):[about 6p.]. Disponível em: http://dx.doi.org.ez133.periodicos. capes.gov.br/10.1016/j.jvoice.2007.04.005.

9. Ribas TM, Penteado RZ, Garcia-Zapata MTA. Quality of life related with the voice of teachers: exploratory systematic review of literature. Rev. CEFAC [Periódico da Internet]. 2014 [acesso em 2015 ago 11];16(1):[about 12p.]. Disponível em: http://dx.doi.org/10.1590/1982-021620144812.

10. BRASIL. Ministério da Educação. Expansão da Rede Federal 2014. [acesso em 2015 set 12]. Disponível em: http://redefederal.mec.gov.br/ expansao-da-rede-federal.

11. BRASIL. Ministério da Educação. História do Instituto Federal de Alagoas 2015. [acesso em 2016 jan 03]. Disponível em: http://www2.ifal.edu. $\mathrm{br} /$ ifal/reitoria/historia.

12. BRASIL. Ministério da Educação. Um novo modelo em educação profissional e tecnológica: concepção e diretrizes 2010. [Acesso em 2015 set 17]. Disponível em:http:// portal.mec.gov.br/index.php?option $=\mathrm{com}_{-}$ docman\&view = download\&alias $=6691$-ifconcepcaoediretrizes\&category_slug = setembro2010-pdf\&ltemid $=30192$.

13. Fleck MA, Louzada S, Xavier M, Chachamovich E, Vieira $G$, Santos $L$ et al. Aplicação da versão em português do instrumento abreviado de avaliação de qualidade de vida "WHOQOL/breve. Rev Saúde Pública [Periódico da Internet]. 2000 [acesso em 2016 jun 23]; 34(2):[about 6p.]. Disponível em: http://www.scielo.br/scielo.php?script=sci_arttext\& pid $=$ S0034-89102000000200012.

14. Ferreira LP, Giannini SPP, Latorre MRDO, Zenari MS. Distúrbios da voz relacionados ao trabalho: proposta de um instrumento para avaliação em professores. Disturb. Comunic. [Periódico da Internet]. 2007 [acesso em 2016 mar 10]; 19(1):[about 10p.]. Disponível em: https://revistas.pucsp.br/index.php/dic/article/ download/11884/8601.

15. Hogikyan ND, Sethuraman G. Validation of an instrument to measure voice-related quality of life (V-RQOL). J Voice [Periódico em Internet].1999 [acesso em 2016 jun 23]; 13(4):[about 12p.]. Disponível em: http://link-periodicos-capes-gov-br. ez133.periodicos.capes.gov.br.

16. Ministério da Educação (Mec) Instituto Nacional de Estudos e Pesquisa (INEP). Estudo exploratório sobre o professor brasileiro: Com base nos resultados do Censo Escolar da Educação Básica 2007[Periódico da Internet]. 2009 [acesso em 2016 jun 26]. Disponível em: http://portal.mec.gov.br/ dmdocuments/estudoprofessor.pdf.

17. Marçal CCB, Peres MA. Alteração vocal auto-referida em professores: prevalência e fatores associados. Rev Saúde Pública [Periódico da Internet]. 2011 [acesso em 2016 jun 15];45(3):[about 8p.]. Disponível em: http:// www.scielo.br/scielo.php?script =sci_arttext\& pid $=$ S0034-89102011000300008.

18. Ortiz E, Costa EA, Spina AL, Crespo AN. Proposta de modelo de atendimento multidisciplinar para disfonias relacionadas ao trabalho: estudo preliminar. Rev Bras Otorrinolaringol. [Periódico da Internet]. 2004 [acesso em 2016 out 17];70(5): [about 6p.]. Disponível em: http://www.scielo.br/ scielo.php?script $=$ sci_arttext $\&$ pid $=$ S003472992004000500003\&lng=en. http://dx.doi. org/10.1590/S0034-72992004000500003.

19. Behlau M, Azevedo R, Pontes P. Conceito de voz normal e classificação das disfonias. In: Behlau M (org). Voz: O Livro do Especialista. 1a ed. Rio de Janeiro: Revinter; 2001. p.53-84.

20. Carvalho OF de, Souza FH de. Formação do docente da educação profissional e tecnológica no Brasil: um diálogo com as faculdades de educação e o curso de Pedagogia. Educ. Soc. [Periódico da Internet], 2014 [acesso em 2016 jun 15];35(128):[about 25p.]. Disponível em: http:// dx.doi.org/10.1590/ES0101-73302014124974.

21. Servilha EAM, Justo FA. Relação entre percepção de ruído em sala de aula autorreferida por professores universitários e suas consequências sobre a voz. Distúrb. Comun. [Periódico da Internet] 
2014. [acesso em: $2016 \mathrm{dez}$ 13]; 26(4):[about 7p.].Disponível em: https://revistas.pucsp.br/index. php/dic/article/viewFile/18080/15966.

22. Jardim R, Barreto SM, Assunção AA. Condições de trabalho, qualidade de vida e disfonia entre docentes. Cadernos de Saúde Pública [Periódico da Internet]. 2007 [acesso em 2016 jun 08];23(10):[about 22p.]. Disponível em: http:// dx.doi.org/10.1590/S0102-311X2007001000019.

23. Medeiros JSA, Santos SMM, Teixeira LC, Gama ACC, Medeiros AM. Vocal symptoms reported by teachers with dysphonia and associated factors. Audiol. Commun. Res. [Internet]. 2016 [cited on 2016 Jun 24th]; 21:e1553. Available from: http://www.scielo.br/scielo.php?script=sci_ arttext\&pid =S2317-64312016000100304\&lng = pt. Epub 31-May-2016. http://dx.doi. org/10.1590/2317-6431-2015-1553.

24. Servilha EAM, Pereira PM. Condições de trabalho, saúde e voz em professores universitários. Rev Ciênc Méd. [Periódico na Internet]. 2008 [acesso em 2016 jun 26];17(1):[about 10p.]. Disponível em: http://periodicos.puc-campinas.edu.br/seer/index. php/cienciasmedicas/article/view/741.

25. Araújo TM, Reis EJFB, Carvalho FM, Porto LA, Reis IC, Andrade JM. Fatores associados a alterações vocais em professoras. Cadernos de Saúde Pública [periódico na Internet]. 2008 [acesso em 2016 jun 26];24(6):[about 10p.]. Disponível em:http://www.scielosp.org/scielo.php?script=sci_ arttext\&pid=S0102-311X2008000600004.

26. Araújo RP. Perfil dos beneficiários do INSS em auxílio-doença por distúrbios benignos da voz. RBMT [Periódico na Internet]. 2014 [Acesso em 2016 jun 19];1:[about 7p.]. Disponível em: http:// www.anamt.org.br/site/upload_arquivos/revista_ brasileira_de_medicina_do_trabalho_volume_12_n \%C2\%BA_1_25320141526487055475.pdf.

27. Silva GJ, Almeida AA, Lucena BTL, Silva MFBL. Vocal symptoms and self-reported causes in teachers. Rev. CEFAC [Periódico na Internet]. 2016 [acesso em 2016 nov 15]; 18(1):[about 8p.]. Disponível em: http://www.scielo.br/ scielo. php? script $=$ sci_issuetoc $\&$ pid $=1516$ $184620160001 \&$ Ing $=$ en\&nrm $=$ iso.

28. Ferracciu CCS. Distúrbio de voz relacionado ao trabalho e estratégia de enfrentamento em professoras da rede pública estadual de Alagoas [Tese]. Rio de Janeiro (RJ): Escola Nacional de Saúde Pública Sérgio Aroucha-ENSP; 2013.
29. Ministério da Saúde e do Instituto Brasileiro de Geografia e Estatística (IBGE) 2014, Pesquisa Especial de Tabagismo do IBGE (PETab). Ministério da Saúde [Periódico na Internet]. 2014 [acesso em 2016 out 18]. Disponível em: http://portalsaude. saude.gov.br/index.php/cidadao/principal/agenciasaude/15973-numero-de-fumantes-no-brasil-cai20-5-em-cinco-anos.

30. Giannini SPP, Latorre MRDO, Ferreira LP. Voice disorders (dysphonia) in public school female teachers working in Belo Horizonte. Rev. Soc. Bras. fonoaudiol. [Periódico na Internet]. 2010 [acesso em 2016 out 02]; 15(3):[about 3p.]. Disponível em: http://www.scielo.br/ scielo.php?script $=$ sci_arttext\&pid $=$ S1516$80342010000300025 \&$ lng $=$ pt. $\quad$ http://dx.doi. org/10.1590/S1516-80342010000300025.

31. Morais EPG, Azevedo RR, Chiari BM. Crosssectional study on voice self-assessment, and quality of life in voice of female teachers. Rev. CEFAC [Internet]. 2012 [cited on 2016 jul 12th];14(5):892-900. Available from:http://www. scielo.br/pdf/rcefac/v14n5/121-11.pdf DOI: http:// dx.doi.org/10.1590/S1516- 18462012005000032.

32. Lima-Silva MFB, Ferreira LP, Oliveira IB, Silva MAA, Ghirardi ACAM. Voice disorders in teachers: self-report, auditory-perceptive assessment of voice and vocal fold assessment. Rev soc bras fonoaudiol. [Internet]. 2012 Dez [cited on 2016 nov 15th];17(4):391-7. Available from: http:// www.scielo.br/pdf/rcefac/v18n1/1982-0216rcefac-18-01-00158.pdf DOI: http://dx.doi. org/10.1590/S1516-80342012000400005.

33. Caporossi C, Ferreira LP. Sintomas vocais e fatores relativos ao estilo de vida em professores. Rev. CEFAC [Periódico na Internet]. 2011 [acesso em 2015 jul 15];13(1):[about 7p.]. Disponível em: http:// dx.doi.org/10.1590/S1516-18462010005000099.

34. Anhaia TC, Klahr PS, Cassol M. Association between teaching experience and voice self-assessment among professors: a crosssectional observational study. Rev. CEFAC [Periódico na Internet]. 2015 [acesso em 2015 jul 12];17(1):[about 5 p.]. Disponível em: http://www.scielo.br/scielo.php?script $=$ sci arttext\&pid=S1516-18462015000100052\&lng =en\& $\mathrm{nrm}=\mathrm{iso} \&$ tIng $=\mathrm{en}$.

35. Andrade VCF, Andrade PCR, Leite AMP, Araújo $\mathrm{CM}$. Qualidade de vida de servidores técnicoadministrativos: um estudo de caso. Unincor 
[Periódico na Internet]. 2012 [acesso em 2016 out 23];10(1):[about 8 p.]. Disponível em: http:// revistas.unincor.br/index.php/revistaunincor/article/ view/382/pdf.

36. Pimentel BN, Fedosse E, Rodrigues NGS, Cruz KS, Santos Filha VAV. Perception of noise, hearing health and quality of life of public school teachers. Audiol. Commun Res. [Periódico na Internet]. 2016 [acesso em $2016 \mathrm{dez}$ 13]; 21:1740:[about 7p.]. Disponível em: http://www.scielo.br/ scielo. php? script $=$ sci_arttext \&pid $=$ S2317 $64312016000100332 \& \mathrm{lng}=\mathrm{en} \& \mathrm{nrm}=\mathrm{iso} \& \mathrm{tl}$ $\mathrm{ng}=\mathrm{en}$.

37. Gampel D, Karsch UM, Ferreira LP. Percepção de voz e qualidade de vida em idosos professores e não professores. Ciênc Saúde Coletiva [Periódico na Internet]. 2010 [acesso em 2016 jun 02];15(6):[about 1p.]. Disponível em: http://dx.doi. org/10.1590/S1413-81232010000600028 .

38. Gillivan-Murphy P, Drinnan MJ, O'Dwyer TP, Ridha H, Carding P. The effectiveness of a voice treatment approach for teachers with self-reported voice problems. J Voice [Periódico na Internet]. 2006 [acesso em 2016 nov 15];20(3):[about 8p.]. Disponível em: http://link-periodicoscapes-gov-br.ez133.periodicos.capes.gov.br/ sfxlcl41?url_ver=Z39.88-2004\&url_ctx_fmt $=\mathrm{fi} /$ fmt:kev:mtx:ctx\&ctx_enc=info:ofi.

39. Putnoki DS, Hara F, Oliveira G, Behlau M. Qualidadede vida em voz: o impacto de uma disfonia de acordo com gênero, idade e uso vocal profissional. Rev Soc Bras Fonoaudiol. [Periódico na Internet]. 2010 [acesso em 2016 out 23];15(4):[about 5p.]. Disponível: http://www. scielo.br/pdf/rsbf/v15n4/a03v15n4.pdf.

40. Jardim R, Barreto SM, Assunção AA. Voice disorder: case definition and prevalence in teachers. Rev. Bras Epidemiol. [Periódico da Internet]. 2007 [acesso em 2016 jun 04];10(4):[about 11p.]. Disponível em: $\quad$ http://www.scielo.br/scielo.php?script $=$ sci_ arttext\&pid $=$ S1415-790X2007000400020. 


\section{APPENDIX. Data collection form}

\section{DATA COLLECTION FORM}

If you do not feel comfortable answering a question, you may leave it unanswered.

Date: Gender: Female ( ) Male ( ) Age: years Date of Birth: Level of Performance: Integrated ( ) Subsequent ( ) ProEJA ( ) Graduation ( ) Teaching Time (total in years): Teaching Time in the IFAL (years):

Do you currently work as a teacher elsewhere: Yes ( ) No ( )

No. Of hours of classes you currently teach per week (in IFAL or elsewhere): $\mathrm{h} /$ classes

No. Of students per class (average): Up to 20（） from 21 to 40 ( ) More than 41 ( )

Most used method. Exhibition Classes ( ) Group Work ( ) Others ( )

Do you use your voice constantly in another kind of activity: Yes ( ) No ( ) Which?

Use of voice in everyday life: I speak: little ( ) moderately ( ) Much ( ) Too much ( )

Noise in the classroom: № ( ) Tolerable ( ) Unpleasant ( )

Use chalk in the classroom: No ( ) Sometimes ( ) Frequently ( ) Always ( )

Temperature in the classrooms: Good ( ) Reasonable ( ) Unpleasant ( )

Interval between classes: Always（ ） Sometimes（ ) Never ( )

Drink water during the classes: Always（ ） Sometimes（ ) Never ( )

How much water do you drink a day (in litres): Less than $1 \mathrm{~L}(\quad$ ) Between 1 and $2 \mathrm{~L}(\mathrm{)} \mathrm{More} \mathrm{than} 2 \mathrm{~L}(\quad$ )

Alcoholic Drinks: No ( ) Stopped drinking（） Always（） Special Occasions（）

Smoke: No ( ) Yes ( ) Ex-smoker ( )

If yes, how many cigarettes a day on average: For how long (in years):

If ex-smoker, how long ago did you stop smoking?: How many cigarettes a day on average?

Did you see a doctor or speech-language pathologist because of voice problems? Yes ( ) No ( )

Did you seek guidance on voice usage professionally? Yes（） No（ ）

Have you had medical leave or left work for a while because of voice problems:: Yes ( ) No ( )

In the last six months did you have episodes of: Respiratory allergy ( ) Asthma ( )

Rhinitis and/or Sinusitis ( ) Depression related to voice limitation ( )

Pharyngitis and / or Laryngitis and / or Tonsillitis ( ) Gastritis and / or Reflux and / or Heartburn ( )

Vocal or throat symptoms in the last six months: Hoarseness ( ) Voice failure ( )

Cough ( ) Dry throat ( ) Loss of voice ( ) Throat pain or burning ( ) Tiredness when speaking ( )

Discomfort when speaking ( ) Voice varying thin/thick ( ) Weak voice ( )

NOTE: The issues that comprise this instrument are based on other forms available in scientific articles of Speech-Language Therapy. 